\title{
Actinomycosis of the reproductive organs - Own experience
}

\author{
Dobrosława L Sikora-Szczesniak* and Izabela Lewandowska-Andruszuk \\ Department of Gynecology and Obstetrics, Specialist Hospital in Radom, Poland
}

\begin{abstract}
Aim: Actinomycosis is a rare chronic infectious disease caused by microbes of low virulence. The infection occurs when the tissue barrier gets broken, often in cases of decreased immunity. The disease usually develops as a consequence of trauma, surgery, endoscopic procedure or the presence of a foreign body.

Material and methods: The paper discusses 10 cases of actinomycosis affecting the reproductive organs.

Results: In 10 cases, the primary reason for hospitalization was pain related to inflammatory lesions and nodules: in 9 cases located in the small pelvis or abdominal cavity, and one in the post-incisional scar in the perineum. One case of septic shock was reported, in two cases the patients were examined for adnexal proliferation. On vaginal examination, the lesions presented as fixed nodules hindering or preventing reliable assessment of the pathology. In 10 cases, patients used intrauterine devices (IUDs) containing copper. Only one patient did not undergo surgical intervention.

Conclusions: In the case of actinomycosis, diagnostic difficulties and suspected cancer of the reproductive organs frequently lead to surgical intervention. Developing effective screening for patients exposed to actinomycosis may allow for effective pharmacological treatment and reduction of unnecessary surgical interventions. All abnormal lesions require oncological vigilance.
\end{abstract}

\section{Introduction}

Adnexal tumors are a medical problem that affects women at different stages in their lives. They pose a diagnostic challenge as it necessitates the exclusion of malignant nature of the lesion. It should be mentioned however, that despite advances in therapy, the 5-year survival depending on the grade of ovarian cancer is 19 to $90 \%$ [1]. Pathological lesions may localize in the ovaries, fallopian tubes, surrounding tissues, and may also occur interstitially.

Ultrasound examination is the main diagnostic method; the scans infrequently suggest the suspicion of cancer. Then it requires supplementary diagnostics by CT or MRI. According to the literature, $5-10 \%$ of women undergo gynecological surgery for adnexal tumors at some point in their lives [2].

Inflammatory nodules, abscesses or fistulas are often caused by Gram-positive bacteria, mainly anaerobic Actinomyces. Actinomycosis is a rare chronic infectious disease, however the microbe virulence is not high [3-6]. For the infection to develop it is necessary to break the tissue barrier or decreased immunity [3-9]. The disease usually results from trauma, surgery, endoscopic procedure or the presence of a foreign body.

There are several forms of actinomycosis: cervical-facial (31-65\%), thoracic (15-33\%), abdominal (10-36\%), and pelvic (approx. 3\%) $[7,10-14]$. In general, actinomycosis is more common in men, but the situation changes with regard to the location in the abdomen and small pelvis. Considering that, women are five times more often affected, which is related to the use of intrauterine devices (IUDs) for birth control [15-18].

The paper presents 11 cases of actinomycosis affecting the reproductive organs and small pelvis among patients from Radomski region, including one unrelated to the use of IUD, located in the postincisional perineal scar.

\section{Material and methods}

In the years 1998-2018, 11 cases of actinomycosis were recorded among the inhabitants of Radomski region. The study analyzed the age of patients, place of residence, parity, clinical symptoms, duration of IUD use and type of IUD, time from the IUD removal to surgery, initial diagnosis, type of surgical treatment, postoperative diagnosis, histopathological findings, and treatment.

\section{Results}

The average age of patients was 39 years, the youngest woman was 24 and the oldest 48 . The majority of patients lived in rural areas. One of the city inhabitants was involved in farming. Table 1 presents data on parity, body weight and BMI.

In 10 cases the primary reason for hospitalization was pain associated with the presence of inflammatory or nodular lesions: in 9 cases in the small pelvis or abdominal cavity, in one case in the postincisional perineal scar. One patient was diagnosed with actinomycosis after diagnostic uterus dilation and curettage $(\mathrm{D} \& \mathrm{C})$ prior to the elective surgery for hysterectomy due to fibroids. In addition, one case of septic shock was noted because the patient reported for treatment

*Correspondence to: Dobrossawa L Sikora-Szczssniak, Gynecological Ward. Radom, Poland, Radomski Specialist Hospital,26-610 Radom, Tochtermana, Poland, E-mail: dosiass@wp.pl

Received: September 04, 2019; Accepted: September 19, 2019; Published: September 23, 2019 
too late despite pain. In two cases, the patients were examined for adnexal proliferation.

The majority of patients were periodically treated on outpatient bases for vaginal discharge, spotting, vaginal bleeding, and lower abdominal pain. In four cases, patients were transferred from the Department of Surgery.

On transvaginal examination, most of the lesions presented as fixed nodules or pelvic infiltrates hindering or preventing reliable

Table 1. Patients' characteristics $(\mathrm{N}=11)$

\begin{tabular}{|c|c|c|c|c|}
\hline Patient & Age & $\begin{array}{c}\text { Body weight } \\
\text { (kg) }\end{array}$ & BMI & $\begin{array}{c}\text { No of deliveries } \\
\text { (miscarriages) }\end{array}$ \\
\hline 1 & 42 & 52 & 19.3 & $4(3)$ \\
\hline 2 & 40 & 64 & 22.1 & $2(0)$ \\
\hline 3 & 24 & 60 & 19.6 & $1(0)$ \\
\hline 4 & 42 & 68 & 22.2 & $2(1)$ \\
\hline 5 & 37 & 55 & 20.5 & $3(0)$ \\
\hline 6 & 44 & 63 & 23.7 & $2(0)$ \\
\hline 7 & 48 & 78 & 28.7 & $3(1)$ \\
\hline 8 & 37 & 55 & 20.2 & $2(0)$ \\
\hline 9 & 39 & 44 & 18.1 & $6(1)$ \\
\hline 10 & 42 & 61 & 22.8 & $4(0)$ \\
\hline 11 & 38 & 50 & 18.8 & $3(1)$ \\
\hline
\end{tabular}

assessment of the pathology. In 9 patients transvaginal ultrasound showed pathological lesions in the projection of the appendages or in the pouch of Douglas. Considering those findings, the patients were qualified for surgical treatment. In four cases CA 125 was determined (the results were within the norm). Three patients underwent D\&C prior to elective surgery.

The average time of using IUD was 7.4 years. The longest time of IUD remaining in the uterus was 16 years, the shortest 4 years (Table 2 ). The analysis found the intrauterine system (IUS) was removed intraoperatively in one case, in 9 cases prior to surgery - on average 12.5 days (Table 2). All IUDs were copper-types.

Table 3 presents initial diagnosis, scope of surgery, and postoperative histopathological results. The definite diagnosis of actinomycosis was made after histopathological verification: in 3 cases it was confirmed during diagnostic process, in 8 cases during surgery. In one case actinomycosis was detected in the uterine scrapings after $\mathrm{D} \& \mathrm{C}$ which allowed for abandoning the abdominal surgery.

After Actinomyces were detected histopathologically, prompt treatment with penicillin and its derivatives was implemented. The treatment was uneventful.

Table 2. Type of IUD and length of carrying

\begin{tabular}{|c|c|c|c|c|c|c|}
\hline & Age & IUD type & IUD use (yrs) & & IUD removal & \\
\hline & & & & Preoperatively & Intraoperatively & $\begin{array}{c}\text { Duting diagnostic } \\
\text { procedure }\end{array}$ \\
\hline 1 & 42 & $\mathrm{CU}$ & 16 & - & & $(+)$ \\
\hline 2 & 40 & $\mathrm{CU}$ & 5 & - & $(+)$ & \\
\hline 3 & 24 & No IUS & - & - & - & - \\
\hline 4 & 42 & $\mathrm{CU}$ & 6 & 10 days & & $(+)$ \\
\hline 5 & 37 & $\mathrm{CU}$ & 5 & 10 days & & $(+)$ \\
\hline 6 & 44 & $\mathrm{CU}$ & 9 & 5 days & & \\
\hline 7 & 48 & $\mathrm{CU}$ & 6 & 1 day & & \\
\hline 8 & 37 & $\mathrm{CU}$ & 4 & 2 months & & \\
\hline 9 & 39 & $\mathrm{CU}$ & 10 & 2 days & & \\
\hline 10 & 42 & $\mathrm{CU}$ & 6 & 7 days & & \\
\hline 11 & 38 & $\mathrm{CU}$ & 7 & 5 days & & \\
\hline
\end{tabular}

Table 3. Preoperative diagnosis, type of surgery, and histopathological findings

\begin{tabular}{|c|c|c|c|c|}
\hline Patient & Age & Preoperative diagnosis & Procedure & Histopathological diagnosis \\
\hline 1 & 42 & $\begin{array}{l}\text { Inflammatory nodule in pouch of } \\
\text { Douglas }\end{array}$ & $\mathrm{D} \& \mathrm{C}$ & actinomycosis \\
\hline 2 & 40 & $\begin{array}{l}\text { Inflammatory nodule in Douglas Bay. } \\
\text { Pelvic peritonitis }\end{array}$ & $\begin{array}{l}\text { Laparotomy. Removal of left adnexa. Tansvaginal } \\
\text { removal of IUD }\end{array}$ & Actinomycosis cum pyoovario. Pyosalpinx et perisalpingitis chronica. \\
\hline 3 & 24 & $\begin{array}{l}\text { Suspicion of endometriosis in post- } \\
\text { incisional pereneal scar on the left }\end{array}$ & Removal of perineal nodule & actinomycosis \\
\hline 4 & 42 & Uterine leiomyomas & 1. $\mathrm{D} \& \mathrm{C}$ & 1. actinomycosis \\
\hline 5 & 37 & Tubo-ovarian abscess (left) & $\begin{array}{c}\text { 1. D\&C } \\
\text { 2.Laparotomy. Adnexectomy (left). Release of } \\
\text { adhesions. }\end{array}$ & $\begin{array}{l}\text { 1. actinomycosis } \\
\text { 2.pyosalpinx et pyoovariorum }\end{array}$ \\
\hline 6 & 44 & $\begin{array}{l}\text { Inflammatory nodule in small pelvis. } \\
\text { Obstruction of alimentary tract. }\end{array}$ & $\begin{array}{l}\text { Laparotomy. Hysterectomy with adnexectomy. } \\
\text { Evacuation of abscesses from abdominal cavity. } \\
\text { Release of adhesions. }\end{array}$ & Actinomycosis ovarii. Pyosalpinx et pyovariorum bilateralis. \\
\hline 7 & 48 & Adnexal tumor (right) & Laparotomy. Adnexectomy (right) & Actionomycosis ovarii cum pyoovarium \\
\hline 8 & 37 & Ovarian tumor (left). Septic shock & $\begin{array}{l}\text { Laparotomy. Adnexectomy (left). Appedectomy. } \\
\text { Drainage of pouch of Douglas }\end{array}$ & $\begin{array}{l}\text { Actionomycosis ovarii. Salpingitis chronica exacerbata. Appendicitis } \\
\text { chronica et perappendicitis chronica exacerbata }\end{array}$ \\
\hline 9 & 39 & Bilateral adnexitis. Pelvic peritonitis & $\begin{array}{l}\text { Laparotomy. Adnexectomy (left). Drainage of } \\
\text { pouch of Douglas }\end{array}$ & $\begin{array}{c}\text { Pyosalpinx et pyoovariorum atqe actinomycosis. Fibrosis et inflammation } \\
\text { chronica exacerbate telae adipose omenti. }\end{array}$ \\
\hline 10 & 42 & Adnexitis (left). Tubal abscess (left) & $\begin{array}{l}\text { Laparotomy. Removal of tumor from greater } \\
\text { omentum }\end{array}$ & $\begin{array}{l}\text { Chronic, exacerbated inflammatory infiltrates with suppuration in } \\
\text { numerous omentum fragments. Foci of actinomycosis in suppuration. }\end{array}$ \\
\hline 11 & 38 & Adnexitis (left). Pelvic peritonitis & Laparotomy. Adnexectomy (right). Appendectomy & $\begin{array}{l}\text { Actinomycosis ovarii. Salpingitis chronica. Appendicitis chronica et } \\
\text { perappendicitis chronica exacerbata }\end{array}$ \\
\hline
\end{tabular}




\section{Discussion}

The frequency of using reversible long-acting contraception (LARC) methods has increased fivefold in the last ten years. Among them, the IUD is the most popular, used by $6.4 \%$ of women aged $15-$ 44 to prevent pregnancy [19]. The contraceptive is well-tolerated and therefore approximately $80 \%$ of the women decide to continue having an IUD [20]. It has to be mentioned that this form of birth control is often used in patients with a history of contraindicated estrogencontaining contraceptives.

Unfortunately, each implanted IUD increases the risk of infection in the small pelvis, especially in the first month after the insertion [21]. The report by Sánchez-Guerrero on contraceptive methods in women with systemic lupus erythematosus found a greater proportion of infectious complications in women using copper IUDs. However, the degree of immunosuppression that excludes IUD insertion has not been established [22].

Actinomyces responsible for actinomycosis, a special type of IUDrelated uterine infection, belong to the saprophytic flora, so they are causative factors of endogenous infections [23-27]. They reside mainly in the mouth. Either Actinomyces israelii or Actinomyces gerencseriae. $P$ [28] is responsible for nearly $70 \%$ of the infections.

After breaking through the barrier of mucosal membrane, the bacteria invade the surrounding tissues, and the mechanism of chronic ongoing infection leads to tissue hardening and fibrosis as well as the formation of purulent fistulas [24]. Once Actinomyces spp. have invaded the tissues, they develop a chronic granulomatous infection characterized by the formation of tiny clumps, called sulfur granules because of their yellow color being a cluster of filamentous forms of bacteria. These clumps indicate the host's immune response to infectious and non-infectious antigens, and are often observed in rare fungal infections, nocardiosis, or other bacterial infections [29]. Splendore-Hoeppli phenomenon develops, with typical complexes of Acinomycete colonies surrounded by eosinophils [30].

Diagnostic difficulties are associated with the need to use special culture methods and appropriate media. In addition, actinomycosis often coexists with other microorganisms, such as Aggregatibacter actinomycetemcomitans, Prevotella, Streptococcus, Enterobacteriaceae, Peptostreptococcus and Staphylococcus [31-33].

The abdominal-pelvic form of actinomycosis usually manifests as slow-growing inflammatory foci, most often in the large intestine, caecum, appendix, urinary tract, abdominal wall, perianal area, in the ovaries, and fallopian tubes [13,16,18,23,25-27,34,35]. Clinical manifestations are often nonspecific. Patients report abdominal pain, malaise, excessive discharge from the genital tract, bleeding or spotting may also occur. General symptoms include fever, weight loss, lack of appetite, nausea, and vomiting. The complete clinical picture of abdominal and pelvic actinomycosis can mimic a tumor growth, often suspected of being far advanced [36,37]. Abnormally grown masses can press upon adjacent organs, hence there are also symptoms suggestive of gastrointestinal obstruction $[9,11,15,17,23]$.

In the presented material, the majority of patients reported nonspecific pains. In 9 cases abnormal masses were diagnosed in the small pelvis, in one actinomycosis was located in the post-incisional perineal scar. Two patients were examined for the symptoms of neoplastic process. In one case, actinomycosis was diagnosed prior to hysterectomy with adnexa due to uterine fibroids in the material after D\&C. It is worth mentioning that 4 patients were transferred from the Department of Surgery where they were treated for abdominal tumor. In eight cases of inflammatory lesions in the small pelvis, the final diagnosis of abscess located in the ovaries, fallopian tubes and surrounding tissues was made.

Similarly, Bednarek et al. reported a case of a 43-year-old female patient admitted to the Clinic for pain in the lower abdomen lasting for 2 months. She was diagnosed with the inflammation of the reproductive organs, and an abscess was found in Douglas Bay. Initially she was diagnosed with peritonitis, which prompted a decision of urgent surgery [23]. Similar reports can be found in the works of other authors [24- 27].

In our material, all cases were IUD-related actinomycosis as all patients used IUDs, except for actinomycosis in the post-incisional perineal scar. One patient was carrying an IUD for 16 years. According to the literature, up to $70-80 \%$ of the patients infected with Actinomyces used IUDs for at least 5 years [11]. All IUSs contained copper. Therefore, it can be concluded that there is a causal relationship between actinomycosis development and using those contraceptives. According to the literature, IUD alters the metabolism of carbohydrate in the endometrial cells, contributing to the intensity of inflammation [38].

In 1994, Barwijuk and Czekanowski proposed cervical swabs for Actinomyces to be taken in the women carrying an IUD who suffered disturbing symptoms. They even postulated such tests should be carried out every two years or more often [39]. Other researchers also emphasized the need for such monitoring $[4,7,11]$. The presence of actinomycosis was confirmed in genital swabs in $25 \%$ of patients carrying an IUS and suffering mild symptoms of pelvic infection $[4,11]$.

Microbiological diagnosis prior to surgery allows for the implementation of effective antibiotic therapy. The use of crystalline penicillin may gradually decrease the inflammatory foci, and in some cases, it is possible to avoid surgery [40]. It is also necessary to remove the gates of potential infection - in the presented material it was an intrauterine device. In one case presented by the authors, the diagnosis was made on the basis of histopathological examination of the uterine scrapings, and the implemented pharmacological treatment brought expected positive effect.

Unfortunately, actinomycosis is most often diagnosed postoperatively, based on histopathological examination of resected tissues. Hard inflammatory infiltrates, abscesses and fistulas, and sometimes "sulfur granules" in the pus (sulfur grains) facilitate the suspicion of actinomycosis.

Atypical locations of actinomycosis are also worth mentioning. In the examined material one patient was diagnosed with actinomycosis in the scar after episiotomy. Initially, endometriosis in the perineal scar was suspected. In this case, no IUD was used. No literature data were found regarding this clinical situation. Another rare location of actinomycosis was the greater omentum.

Proper long-term antibiotic therapy and surgical treatment offer chances for therapeutic success in the treatment of actinomycosis. Only accurate diagnosis and treatment can prevent complications and disease relapses.

\section{Conclusion}

1. In the case of actinomycosis, diagnostic difficulties and suspected cancer of the reproductive organs frequently lead to surgical intervention. 
2. Developing effective screening for patients exposed to actinomycosis may allow for effective pharmacological treatment and reduction of unnecessary surgical interventions.

3. All abnormal lesions require oncological vigilance.

\section{References}

1. Kotarski J, Marzec- Kotarska B, Tarkowski R, Perspektywy WI (2017) Ginekologia onkologiczna. PZWL, Warszawa 4: 19-32.

2. Winiarek J, Timorek A, Cendrowski K, Sawicki W, Knec K, et al. (2017) Guzy przydatków. Ginekologia po Dyplomie tom 19: 53-57.

3. Bonnefond S, Catroux M, Melenotte C, Karkowski L, Rolland L. et al. (2016) Clinical features of actinomycosis; A retrospective, multicenter study of 28 cases of miscellaneous presenttions. Medicine (Baltimore) 95: e3923.

4. Boyanova L, Kolarov R, Mateva L, Markovska R, Mitov I. et al. (2015) Actinomycosis a frequently forgotten disease. Future Microbiol 10: 613-628.

5. Lisa-Garcia M, Martin-Rivas B, Pajaron-Guerrero M, Arnaiz-Garcia A (2017) Abdominal actinomycosis in the last 10-year risk factors for appendiceal actinomycosis: review of the literature. Turk J Med Sci 47: 98-102.

6. Nakahira ES, Maximiano LF, Lima FR, Ussami EY (2017) Abdominal and pelvic actinomycosis due to longstanding intrauterine device: a slow and devastating infection. Autops Case Rep 7: 43-47

7. Zamani F, Sohrabi M (2015) Clinical, endoscopic, and histopathological aspects of sigmoid actinomycosis; a case report and literature review. Middle East J Dig Dis 7: $41-44$.

8. Liu K, Joseph D, Lai K, Kench J, Ngual MC, et al. (2016) Abdominal actinomycosis presenting as appendicitis: two case reports and review. J Surg Case Rep 5: rjw068. [Crossref]

9. Ridha A, Oguejiofor N, Al-Abayechi S, Njoku E (2017) Intra- Abdominal Actinomycosis Mimicking Malignat Abddominal Disease. Case Rep Infect Dis 2017 1972023

10. Baldursdottir E, Jonasson L, Gottfredsson M (2010) The many faces of Actinomycosis. Results from a retrospective study in Iceland, 1984-2007. Laeknabladid 96: 323-328.

11. Boler DE, Uras C, Goksel S, Karaarslan M (2013) Actinomycosis of cecum associated with Entamoeba infection mimicking perforated colon cancer. Case Rep Gastrointest Med 2013: 143218

12. Privitera A, Milkhu CS, Datta V, Rodriguez-Justo M, Windsor A, et al. (2009) Actinomycosis of the sigmoid colon: A case report. World J Gastrointest Surg 1: 62-64

13. Galata CL, Vogelmann R, Gaiser T, Post S, Horisbergeret K, et al. (2015) Abdominopelvic actinomycosis in three different locations with invasion of the abdominal wall and ureteric obstruction: An ucommon presentation. Int J Surg Case Rep 12: 48-51.

14. Rubio Tartosa I, Sanchez Sanchis M, Coronel Sanchez B, Garcia Serrado D, Garcia Torrelles M, et al. (2005) Ureteral actinomycosis. Case report. Arch Esp Urol 58: 351353.

15. Kaszuba M, Tomaszewska R, Pitynski K, Grzanka P, Bazan-Socha S i wsp, et al. (2008) Actinomycosis mimicing advanced cancer. Pol Arch Med Wewn 118: 581-584.

16. Hayashi M, Asakuma M, Tsunemi S, Inoue Y, Shimizu T, et al. (2010) Surgical treatment for abdominal actinomycosis. A report of two cases. World J Gastrointest Surg 2: 405-408.

17. Lee SY, Kwon HJ, Cho JH, Oh JY, Nam KJ, et al. (2010) Actinomycosis of the appendix mimicking appendiceal tumor: a case report. World J Gastroenterol 16: 395-397.

18. Bednarek M, bolt L, Biesiada Z, Habrat W, Demczuk S, et al. (2010) Promienica w przetrwałym moczowniku. Przegl Lek 67: 141-143.

19. Branum AM, Jones J (2015) Trends in long-acting reversible contraception use among U.S women aged 15-44. National Center for Health Statistics Data Brief; 188; February 2015 .
20. Chen XY (2015) Three-dimensional ultrasonography versus two-dimensional ultrasonography for the diagnosis of intrauterine device malposition. Int J Gynaecol Obstet 128: 157-161.

21. Mishell D, Wkladki wewnątrzmaciczne.W: Sammaritano L, Bermans L (2014) Contraception and Pregnancy in Patients with Rheumatic Disease. Mishell D ed. Springer 17-108.

22. Sanchez-Guerrero J, Uribe AG, Jimenez-Santana L, et al. (2005) A trial of contraceptive methods in women with systemic lupus erythematosus. N Engl J Med 353: 2539-2549.

23. Bednarek M, Budzynski P, Trybus M, Szczepanski W i inn (2017) Własne doświadczenia w leczeniu brzuszno-miedniczej postaci promienicy. Przeglad Lek 74: 664-669.

24. Sehnal B, Benes J, Kolarovrova Z, Mojohova M, Zikan M (2018) Pelvic actinomycosis and IUD. Ceska Gynekol 83: 386-390.

25. Dhillon AK, Fairlie N, Finch G (2015) Pelvic Actinomyces israelii abscess: a differential diagnosis of a pelvic mass. BMJ Case Rep 2015: bcr2015211595. [Crossref]

26. Taira Y, Aoki Y (2019) Tube-ovarian abscess caused by Rothia aeria. BMJ Case Rep 12: e229017.

27. Sawtelle AL, Chappell NP, Miller CR (2017) Actinomyces-Related Tubo-Ovarian Abscess in a Poorly Controlled Type II Diabetic with a Copper Intrauterine Device. Mil Med 182: 1874-1876. [Crossref]

28. Sandeep S, Hashmi MF, Valentino III DJ (2019) Actinomycosis.StatPearls. StatPearls Publishing 2019 Jan-.PMID 29489261

29. Roozeboom MH, Westers-Attema A, Winnepenninckx V (2012) Rozne oblicza promienicy. Dermatologia po Dyplomie tom 3: 32-35.

30. Nowica U, Modrzewska K, Pasik P, Burakowska B, Szołkowska M, et al. (2014) Rzadka manifestacja płucna promienicy w postaci zmian rozsianych. Pneumunologia $i$ Alergologia Polska 82: 32-38.

31. Ahmed S, Ali M, Adegbite N, Vaidhyanath R, Avery C, et al. (2019) Actinomycosis of tongue: Rare presentation mimicking malignancy with literature review and imaging features. Radiol Case Rep 14: 190-194. [Crossref]

32. Tippet E, Goyal N, Guy S, Wong J (2019) Actinomyces spp. bloodstream and deep vein thrombus infections in people who inject drugs. Infections 47: 479-482.

33. Mishra A, Prabhuraj AR, Bhat D, Nandeesh BN, Mhatre R (2019) Intracranial Actinomycosis Manifesting as a Parenchymal Mass Lesion: A Case Report and Review of Literature. World Neurosurg 122: 190-194

34. Al-Obaidy K, Alruwaii F, Al Nemer A, Alsulaiman R, Alruwaii Z, et al. (2015) Primary gastric actinomycosis: report of a case diagnosed in a gastroscopic biopsy. BMC Clin Pathol 15: 2. [Crossref]

35. Yang XX, Lin JM, Xu KJ, Wang SQ, Luo TT, et al. (2014) Hepatic actinomycosis report of one case and analysis of 32 previously reported cases. World J Gastroenterol 20: 16372-16376. [Crossref]

36. Paplicki A, Sobiczewski P, Kowalska M, Nowak R, Krzyszkowska I (2013) Promienica miednicy mniejszej o przebiegu klinicznym imitującym zlosliwy guz przydatkow- opi przypadku. Curr Gynecol Oncol 11: 238-243.

37. Zaryjewski D, Malarkiewicz JA, Ciunczyk J, Onichimowski D (2009) Promienica miednicy mniejszej, obejmująca jajnik, jajowód, pęcherz moczowy, odbytnicę i esicę oraz scianę miednicy, imitująca rozsiany proces nowotworowy. Pol Ann Med 16: 120127

38. Garcia-Garcia A, Ramirez-Duran N, Sandoval-Trujillo H, et al. (2017) Pelvic Actinomycosis. J Infect Dis Med Microbiol 2017: 9428650. [Crossref]

39. Barwijuk AJ, Czekanowski R (1994) Przypadek zakażenia promieniowcem narządów jamy brzusznej u kobiety jako powikłanie wieloletniego stosowania wkładki domacicznej-IUD. Gin Pol 65: 204-206

40. Ruiz MP, Williams EM, Markey CM, Johnson AM, Morales-Ramirez PB (2017) Can Surgery Be Avoided? Exclusive Antibiotic Treatment for Pelvic Actinomycosis. Case Rep Obstet Gynecol 2017: 2907135.

Copyright: (C2019 Sikora-Szczesniak DL. This is an open-access article distributed under the terms of the Creative Commons Attribution License, which permits unrestricted use, distribution, and reproduction in any medium, provided the original author and source are credited. 